${ }^{\circledR}$ Entomologica Fennica. 10 December 1998

\title{
Taxonomy of the genus Plemyria Hübner (Lepidoptera, Geometridae, Larentiinae)
}

\author{
Sei-Woong Choi
}

\begin{abstract}
Sei-Woong Choi 1998: Taxonomy of the genus Plemyria Hübner (Lepidoptera, Geometridae, Larentiinae). — Entomol. Fennica 9: 185-196.

The Holarctic genus of Plemyria comprising two species, rubiginata (Denis et Schiffermüller) and georgii (Hulst), is revised. Redescriptions of adults including the genitalia as well as larvae and pupae are given. The monophyly of the genus is discussed.

Sei-Woong Choi, Zoological Museum, P.O. Box 17, FIN-00014 University of Helsinki, Finland. Current address: Department of Entomology, American Museum of Natural History, Central Park West at 79th St., New York, N. Y. 10024-5192,USA.E-mail: choisw@amnh.org
\end{abstract}

Received 7 July 1997, accepted 20 June 1998

\section{Introduction}

The genus Plemyria, belonging to the subfamily Larentiinae, is Holarctic in its distribution and it comprises two species: rubiginata (Denis et Schiffermüller 1775) and georgii (Hulst 1896). Fletcher (1979) designated this genus with Geometra rubiginata as the type species.

Meyrick (1892) described the morphology of Plemyria sensu lato (= sensu Meyrick): face with slight cone of scales; palpi moderate, porrected, rough-scaled; male antennae ciliated; thorax glaborous beneath; posterior tibiae with all spurs present; fore wing with areole, simple; hind wing with 8 anastomising with cell from near base to beyond middle. He suggested that this genus is very close to Hydriomena sensu Meyrick and it would originate in Europe, although many species of Plemyria s. $l$. were common in South America. Hulst (1896) diagnosed the genus in his key of geometrid genera of North America by having one accessory cell of fore wing. Prout $(1914,1937)$ listed the genus as one of the subgenus of Cidaria s.l. and also separated it from Cidaria s.s. based on the single areole of fore wing. Pierce (1914) de- scribed the genitalia of $P$. bicolorata Hufnagel (= rubiginata) as follows: valva rounded, costa not thickened; uncus tapered, tip hooked; aedeagus stout; cornuti short, many in patch; anellus lobe peaked, spined along the edge; saccus basally indented; ostium weak; [corpus] bursa subglobular, simple. Forbes (1948) described the close relationship with Dysstroma Hübner and noted some differences in single large accessory cell of fore wing, two large hairy anellus lobes in male genitalia. He described the immature stages as "larva very slender, smooth, green with yellow subdorsal line, and two white points on posterior side of anal prolegs, and pupa in a slight cocoon between leaves". McGuffin (1958) examined the larvae of $P$. georgii, and discussed the general characters and the systematic relationship with related species. Patocka $(1994,1995)$ showed the pupal characters of $P$. rubiginata. Choi (1997) defined the monophyly of the genus using one species of Plemyria.

The genus Plemyria has been included into two tribes, Hydriomenini sensu Forbes and Cidariini sensu Herbulot. For example, in North America, Forbes (1948), McGuffin (1958) and Ferguson 
(1983) listed the genus Plemyria under the Hydriomenini. In middle Europe, however, Herbulot (1961-62) and Leraut (1980) listed it under the Cidariini. In these two tribes the relationships between Plemyria and sister taxa were as follows: Hydriomena + Thera + Plemyria (Forbes 1948); Cidaria + Plemyria + Thera (Herbulot 1961-62), respectively.

Plemyria rubiginata is widely spread in the Palaearctic region from northern Europe to the Far East and two subspecies are known, dahurica Staudinger, 1892 and japonica Inoue, 1955. P. georgii is distributed in the Nearctic region and one subspecies is known, benesignata Barnes et McDunnough, 1917.

This work is carried out during the generic revision of Cidariini sensu Herbulot to clarify the species relationship between Palaearctic and $\mathrm{Ne}$ arctic regions. Thus, the main purpose is to revise the Holarctic genus of Plemyria based on larval, pupal and adult characters.

\section{Materials and methods}

The materials examined in this study were obtained from the following museums (with acronyms within the text): American Museum of Natural History, New York (AMNH), British Museum of Natural History, London (BMNH), Hungarian Natural History Museum, Budapest (HNHM), Museum of comparative Zoology, Harvard University, Cambridge (MCZ), Museum für Naturkunde der Humboldt-Universität zu Berlin (MNHU), and Zoological Museum, University of Helsinki, Helsinki (ZMH).

For the general method of genitalia examination I referred to Hardwick (1950). Terminology of adult and immature morphology followed those of Forbes (1948), McGuffin (1958) and Patocka (1994).

\section{Systematics}

\section{Plemyria Hübner, 1825:327}

Type species. - Geometra rubiginata Denis et Schiffermüller, 1775

Diagnosis and monophyly. - The species of Plemyria show a distinct wing pattern: the costal part of central fascia is dark brownish with a large black discoidal dot, but the middle and dorsal parts are missing or very weakly colored, and termens of both the fore and hind wing show the same pattern, a black strongly scalloping subterminal line. The male genitalia show very weak and rounded valva, well-developed long pedunculi and large tube-like juxta and transtilla, and one patch of cornuti of vesica. The antrum of female genitalia, being largely rounded, is distinct.

Plemyria is similar to Cidaria Treitschke and Dysstroma in the genitalia. However, the detailed structures of the genitalia, such as the pedunculi, juxta, anellus lobe and saccus, and wing pattern elements, separate Plemyria from the closely related two genera.

The monophyly of Plemyria was defined by the following derived characters: one accessory cell of fore wing; a black apical streak; straight, short and weakly sclerotized uncus; long anellus lobe; sclerotized antrum; a pair of projections on pronotum; and equal length between XD1-XD1 and XD1-XD2 in larval thorax (Choi 1997).

Description. - Antenna of male filiform. Frons smooth, covered with yellowish or ochreous scales. Labial palp moderate, about 1.5 times as long as eye diameter. Fore wing white (rubiginata) or greyish (georgii); basal part dark ochreous or blackish, basal line double, undulated; antemedial line costally slanted outward; central fascia costally dark ochreous, medially and dorsally absent or narrowed, discoidal dot large, black; subterminal line whitish, scalloped; termen blackish; one large accessory cell. Hind wing whitish or greyish; discoidal dot blackish; termen and subterminal line as in fore wing. Metathorax with blackish tufts.

Male genitalia. - Uncus basally tapering, apically sharp. Tegumen triangular, with basally developed pedunculi. Saccus shallow, broad, medioventrally invaginated. Juxta broad, weakly sclerotized, with developed transtilla. Anellus lobe long, crescent (rubiginata) or digitiform (georgii), with long hairs. Valva simple, membranous, distally wider. Aedeagus slender, membranous, occasionally with sclerotized surface, distally scobinated; vesica with one diverticulum, cornuti a patch of large spinular processes.

Female genitalia. - Papillae anales simple, weakly sclerotized. Apophyses thin, slender. Antrum ventrally funnel-like (rubiginata) or tongueshaped (georgii), sclerotized. Ductus bursae short, with colliculum. Corpus bursae large ovular or slender, signum absent (rubiginata) or long sclerotized band (georgii).

Distribution. - Holarctic. 


\section{Checklist of the genus Plemyria}

rubiginata Denis et Schiffermüller, 1775

georgii Hulst, 1896

\section{Plemyria rubiginata (Denis et Schiffermüller)}

Geometra rubiginata Denis et Schiffermuiller, 1775:114

Phalaena bicolorata Hufnagel, 1767:608

Phalaena abbreviata Haworth, 1809:338

Zerene bicolorata ab. plumbata Curtis, 1837:643

Melanthia bicolorata ab. fumosa Prout, 1898:201

Cidaria bicolorata ab. maritima Strand, 1901:286

Cidaria bicolorata ab. guttata Huene, 1901:318

Plemyria bicolorata ab. bipunctata Hannemann, 1920:122

Larentia bicolorata ab. diadelphata Stauder, 1923:92; Prout, 1938:111

Larentia bicolorata ab. peralbata Stauder, 1923:92

[BMNH, examined]

Larentia bicolorata ab. rosarium Stauder, 1923:92

[BMNH, examined]

Larentia bicolorata ab. completa Rebel, 1910:339

Cidaria bicolorata dahurica Staudinger, 1892:381

Syntypes 3 Ơ $^{\prime \prime}$, Kentei Gebirge, coll. Staudinger [MNHU, examined] syn. $\mathrm{n}$.

Cidaria (Plemyria) rubiginata; Prout, 1914:216

Plemyria rubiginata ab. albovittata Cockayne, 1953:161

Plemyria rubiginata ab. semifumosa Cockayne, 1952:266

Plemyria rubiginata ab. pallidaria Cockayne, 1952:267

Plemyria rubiginata japonica Inoue, 1955:79 Holotype ơ, JAPAN: Karuizawa, Nagano Pref., 19-20. July 1939, H. Inoue [BMNH, examined] syn.n.

Plemyria rubiginata ab. tenebra Inoue, 1955:79

Diagnosis. - The whitish ground colour of wings, ochreous basal part and medially broken central fascia of fore wing and blackish termen with whitish scalloping subterminal line of both wings distinguish $P$. rubiginata from Thera variata (Denis et Schiffermüller). This species is easily separated from $P$. georgii by whitish ground color of wings.

Redescription. - Adults (Fig. 1): Antenna simple, filiform in both sexes. Frons white with yellowish scales on upper part. Labial palp white with brown scales, moderate. Body white. Foreleg white and brown, epiphysis long and brownish. Midleg white, dorsal part of tibia covered with dark brown. Tibial spur formula 0-2-4. Metathorax with black tufts. Wingspan $19-25 \mathrm{~mm}$ in male, $24-28 \mathrm{~mm}$ in female. Fore wing whitish; basal part brown and ochreous, basal line double, deeply dentate; central fascia costally brown and ochreous, medially broken, occasionally continuous to dorsum, discoidal dot large, blackish on mdc and ldc; subterminal line scalloped, white; termen wide, brownish. One large accessory cell, without mdc. Hind wing whitish; discoidal dot blackish on ldc; subterminal line and termen as those of fore wing; mdc half of ldc.

Male abdomen and genitalia (Figs. 3-4). 8 th sternite and tergite with weakly sclerotized plate, triangular in shape. Uncus basally tapering, apically sharp. Tegumen triangular, slender. Vinculum laterally parallel, saccus mediodorsally concave. Transtilla and juxta very long, tube-like, membranous. Anellus lobes large, crescent, with long hairs on inside of lobe. Valva simple, membranous. Aedeagus slender, without sclerotization, opening of ductus ejaculatorius at $1 / 3$ from base of vesica. Vesica with one diverticulum, with one patch of sclerotized cornuti.

Female genitalia (Fig. 5). - Papillae anales simple, small. Apophyses thin, slender. Antrum slightly sclerotized, funnel-like. Ductus bursae short, membranous with colliculum. Corpus bursae large, oviform, projected at bottom, without signum.

Immature stages. - Egg: Creamy white, flat. Deep hole middorsally. Length $0.83-0.97 \mathrm{~mm}$; width $0.52-0.55 \mathrm{~mm}$; L/W $1.52-1.8(\mathrm{~N}=6)$. Larva: Head small, yellowish. Labrum smooth, medially invaginated. Spinneret and labial palpi short. Thorax and abdomen pale yellow. Prothorax shield projected, unpigmented, with four setae. Long paraprocts. Crochets of ventral proleg biserial and about 12 in number. H.W. $0.8-0.84 \mathrm{~mm}$; W/L 1.35-1.48; B.L. 28-33 mm; B.W. 1-2 mm $(\mathrm{N}=3$ ). Chaetotaxy. - Head (Fig. 9): P2 posterodorsal of P1, P2-P1-A2 linearly. A3 on the line of A1 and L1. Stemmata (ST) 1-5 in semicircular. Thorax (Fig. 10): Prothorax: Two SD, L and SV with SD2 and L2 thin. Mesothorax: D2 ventral to D1; two SD with SD2 long. Three L setae, L3 anteroventral of L2. One SV. Metathorax: D, SD bisetose. SD, L, and SV as on mesothorax. - Abdomen (Fig. 11): Abdomen 1-6 (A16): D2 posteroventral of D1. SD1 anteroventral of D1. Three L setae, L1 on lateral band with spiracle, L3 posteroventral of L2. Three SV setae, SV3 posterodorsal of SV1, SV2 anteroventral of SV1. One V seta, V1 posteroventral of SV1. Ab- 
domen 7-10 (A7-10): D, SD, and L setae of A7 as on A1-6. One SV seta, SV1 posteroventral of L3. On A8, D and SD as on A7. Bisetous L and SV setae. D2 dorsal of D1 on A9. SD, L, and SV monosetous. $\mathrm{D}$ bisetous. $\mathrm{L}$ and $\mathrm{SD}$ monosetous on anal plate of A10.

Pupa (Fig. 12). - Green, fine sculpture as in Cidaria fulvata (Forster). Exuvium pale whitish yellow. Labrum broad. Foreleg relatively short, hindleg visible. Dorsal channel and lateral cut shallow, long and narrow. Cremaster more or less long and basally broad, tongue-shaped with four setae (Fig. 13) (Patocka 1995).

Overwintering stage. - Egg.

Number of chromosomes (haploid). - 29, 3132 (Suomalainen 1965).

Host plant. - Betula, Alnus, Salix, Ribes, Rosa, Prunus (Seppänen 1954; Patocka 1995). However, Mikkola et al. (1985) noted that the larva mainly feed Alnus and Prunus and occasionally Ribes.

Additional material examined: Finland: $I k$ : Kuokkala, 9.VIII.1939. 1 o', Hellman leg.; Ik: Kuolemanjärvi, 22.VIII.1932. 1 \%, M. Ivaschinzeff leg,; $A b$ : Houtskari, 28.VII.1940. 1 đ’, Lankiala leg.; $N$ :Helsinki, 31.V.1960, 1.V.1978, 5.VI.1981, 4exx., E.O. Peltonen leg.; $N$ :Bromarf, 12.VIII.[19]51, 1 ơ 1 \%. - Sweden: Bl: Asarum, 16.VII.1953. 1 Ơ , E. Sjöholm leg. — Germany: Berl[in]., 12.VII. $10^{\circ}$; Umgebung von Berlin, 1 \&, coll. Winter; $10^{\circ}$ 1 \& Ulm Württbg. coll. Winter (ZMH); Bavaria, Ulm a. $10^{\circ}$ 1 \&, D. E. C. Aichele leg. (BMNH), - Hungary: Hung occ. Szigetköz TYK, Feketeerdö, 12.VI.1989, 1 O’ 1 \& , Ronkay leg.; Budateteny fenycsapda, 28.VI.1963, 1 \&, coll. Dr. L. Ko-

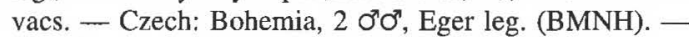
Austria: Alp. c. Tirol s. Innsbruck, 28.VI., $10^{7}$, H. Stauder; Innsbruck, 27.VI.1913, 30.VI.1913, 2 070", J. Felkal (BMNH); Kohfidisch Bgld., 23.VI.1957, 1 O’, Dr. Issekutz leg. (HMNH). - Russia: Irkutsk $40 \mathrm{~km} \mathrm{~N}$, steppe slope, 13.VIII.1984. $10^{7} 2$ 우, Mikkola et Viitasaari leg. (ZMH); Sajan, Siberia, $1 \sigma^{\prime},(\mathrm{BMNH})$. — Russian Far East: Primorje, Gornotajozhnoje, 7-8.VII.1979, 2 0'0 , M. Kruus leg.; Habarovsk, 5-6.VII.1987, 1 0', K. Mikkola leg. -- Japan: Hokkaido, Kaributo, 5.VIII.1966, 1 o', P. Savolainen leg.; Karuizawa, 20.VII.1952, 1 ơ 2 ○ᄋ, P. Savolainen leg.; Karuizawa, 16.VIII.1953, 1 \&, P. Savolainen leg.; Odaira, 25.VIII.1954, 10 , P. Savolainen leg. (ZMH)

Distribution. - Palaearctic region.

Remark. - Staudinger (1892) described a subspecies dahurica from the Mts. Kentei (Hentiyn Nuruu, N. Mongolia) based on about 30 specimens including three females. He distinguished this subspecies by a slightly yellowish color in the basal of wings. However, I found that this yellowish coloration occurs in European specimens, and the specimen with purely whitish wings occurs in Irkutsk, Habarovsk and Japan. In addition, the genitalia examination of the syntypes showed no differences compared to European specimens.

Inoue (1955) designated a subspecies $P$. rubiginata japonica using seven type specimens including one holotype and one allotype. He also recorded one aberration, tenebra, which showed dark costal patches and hind wing.

Wing melanism and shape of central fascia of fore wing have led to many aberrations. However, the genitalia characters of those aberrations are not different from the normal $P$. rubiginata which shows whitish wings and a broken central fascia.

Suomalainen (1965) examined the number of chromosome of Cidaria s. $l$. and reported 29 and 31-32 for $P$. rubiginata. He discussed the number of chromosomes in Lepidoptera and $P$. rubiginata showed a plesiomorphic state that varies between 29 and 31.

\section{Plemyria georgii Hulst}

Plemyria georgii Hulst, 1896:279, Lectotype ơ, labelled "Sept[ember], Nevada Co[unty]. Al. coll[ection]. GD Hulst" [AMNH, examined]

Thera georgii benesignata Barnes et McDunnough, 1917:226, Type O', Wellington, B[ritish] C[olumbia], 28.VII.1905. [not examined] syn. $\mathbf{n}$.

Diagnosis. $-P$. georgii is very close to rubiginata in the wing pattern elements, but differs in brownish ground colour of wings, the shape of anellus lobe being digitiform, large rounded antrum, and one patch of signum of corpus bursae.

Redescription. - Adults (Fig. 2): Antenna of male filiform. Frons smooth, ochreous. Labial palp moderate, about 1.5 times as long as eye diameter. Wingspan $27-29 \mathrm{~mm}$. Fore wing pale greyish; basal part blackish, with undulating blackish subbasal and basal lines; antemedial line blackish, medially indented; postmedial line costally slightly dentate, medially and dorsally undulated; central fascia costally blackish ochreous with black discoidal dot, medially and dorsally narrowed, paler, sometimes blackish at dorsum; termen brownish, subterminal line white, undulated; fringe dotted with black. One large accessory cell. Hind wing pale greyish; postmedial and subterminal line brownish, with small black discoidal dot; fringe black dots. Metathorax with blackish tufts. 
Male genitalia (Figs. 6-7). -- Uncus weakly sclerotized, basally tapering, medially bent, apically pointed. Tegumen triangular, basally with developed pedunculi. Saccus shallow, broad, medioventrally slightly invaginated. Juxta broad, transtilla from tube-like structure. Anellus lobe digitiform, inside and top with long hairs. Valva membranous, distally broader. Aedeagus long, slender, with weakly sclerotized surfaces, distally scobinate; vesica tubular with one large diverticulum, and one patch of large spinular cornuti.

Female abdomen and genitalia (Fig. 8). Eighth segment anteriorly sclerotized. Papillae anales weakly sclerotized. Posterior apophyses long, 5 times length of anterior apophyses. Ostium bursae ventrally broadly tongue-shaped, weakly sclerotized. Ductus bursae short, with colliculum. Corpus bursae long, slender, signum long, sclerotized, band-shaped.

Immature stages. — Larva: McGuffin (1958) described larva of $P$. georgii, which may live from the middle of June until early September, and they spend about 20 days as pupae: Head, cuticle reticulate, pale green or russet-green; sometimes with fine brown markings. Thorax and abdomen rough, covered densely with minute convex spicules, yellow-green, with rose-coloured subspiracular line, intersegmental regions yellow; paraprocts long, pale or rose-coloured. H.W. 1.33-1.52 mm; W/L 1.52-1.54; B.L. 18-23 mm; B.W. 1-2 mm.

Host plant. - Alnus, Salix, Betula (McGuffin 1958).

Additional material examined: California: Laytonville, 20.IX.[19]49, 2 ơ ơ, coll. G. H. and J. L. Sperry; Nelson Cr., Dlumas Co., 29.VIII.[19]40, 1 o", W. R. Bauer; Sier. Nev. $10^{7} 1$ \%, Hy. Edwards; Shasta Retreat, Siskiyou Co., 1 o', coll. O. Buchholz; Garberville, 17.VII.[19]39, 1 ㅇ, W.H. Howe. - Oregon: Eagle Creek, Columbia R. Hiway, 18.VII.1947, 5 ơ ơ, J. H. Baker; Reed, 1-15.IX.1926, 6 070', Ern. McKinney; same locality, 16-31.VIII.1926, $20^{\circ} 0^{\circ}$; 4 mi E. Alleghemy, 9-10.VIII.[19]56, 2 ơ రా, S. G. Jewett; Bev. Beach St. Pk. Lincoln Co., 13.IX.1984, 1 o", J. M. Baker; Dayton, Yamhill Co., 26. VII.1960, 1 O', R. Albright; Vic. Gronnel Rd., ca. 2 mi E. Elsie, Clatsop Co., 10-11.X. [19]64, 18.IX.[19]65, 26.IX.[19]65, 9 ơ 8 우, leg. S. G. Jewett, Jr.; Vic. Firwood Rd., $4 \mathrm{mi} \mathrm{W}$. Oregon City, 20.VI.[19]72, 22.VII.[19]72, 28.VII.[19]72, 26.VIII.[19]72, 2.IX.[19]72, 8 \%ᄋ; Chief Joseph Mt., Joseph, 9.IX.[19]50, 1 ơ, G.H. et J. L. Sperry; Spring Creek, 27.IX.1960, 1 \%, J. H. Baker. - Washington: W. M., 10 , coll. GD Hulst; Mt. Ranier, 22.VIII.[19]47, 1 O', E.C. Johnston; Mineral Park, Skagif Co., 7.IX.[19]36, 1 б'. - British Columbia: Robson, 2.IX.1938, 1 Ơ $^{7}$, R. Foxlee Coll;; Fish lake, Sum- merland, 12.IX.1932, 2 ơ , A.N. Gartrell; Victoria, 8.IX.[19]09, 3.X.[19]01, 29.VIII.[19]09, 5 ơ O', coll. A. J. Crocker; Wellington, Vancouver Island, 17.IX.[19]48, 17.VIII.[19]49, 2.IX.[19]49, 12.IX.[19]49, 29.IX.[19]49, $20^{\circ} 0^{7} 4$ 우, G. H. et J. L. Sperry (AMNH); Victoria, 23. VII.1922. 1 ㅇ, W. Downes; Duncans Vanc. Is., Hannam, 11.IX.[19]20, 1 \%, coll. S. E. Cassino (MCZ). - Alaska: Rampart, 22.IX.[19]71, 1 O': - Alberta: Calgary, F. X. Wolley Dod. 10.VII, 10.IX, 15.IX, $30^{7} 0^{7}$, coll. J. A. Grossbeck; Washington lake, 17.VIII.1949, $20^{\circ 0} 0^{7}$, W. J. et J. W. Gertsch. - Idaho: Wallace, 31.VIII.[19]46, 3.X.[19]43, 16.IX.[19]43, 1 o' 2 фo, coll. O. Huellemann; same locality, 13.VIII.[19]34, $10^{*} 1$ \%, coll. Guedet. - Colorado: Estee Park, 4.IX.[19]38, 1 o 1 ㅇ, G. H. et J. L. Sperry; Salida, 17.VIII.[19]46, 1 ơ. - Arizona: Diamond Rock, White Mts. 6.IX.1947, 2 O'0", G. H. et J. L. Sperry. — Wisconsin: Hazel hurst, 7.VIII.[19]37, 1 O’, G. H. et J. L. Sperry. — Ontario: Tor. 17.VIII. $1 \sigma^{\prime \prime}$, coll. O. Buchholz; Mt. Irwin, Crystal lake, 24-30.VII.1965, 1 ơ 1 ㅇ, leg. W. Plath, Jr. Maine: Rangeley, 25-29.VIII.1936, 5 ơ $^{\circ}$, V.H. dos Passos. - New Hampshire: Franconia, $1 \sigma^{7}$, coll. A. T. Siossou (AMNH); $10^{7}$ without locality, coll. S.E. Cassino (MCZ).

Distribution. - Nearctic: transcontinental (Nova Scotia and Maine, west to British Columbia and Washington)(Forbes 1948; McGuffin 1958).

Remarks. - Rindge (1955) noted the type specimen of $P$. georgii in Hulst's collection of AMNH. According to him, the lectotype was designated by Barnes et McDunnough (1917) using the male from Nevada County, California.

Barnes et McDunnough (1917) described Thera georgii benesignata based on 10 specimens, all from British Columbia. They separated this subspecies from $P$. georgii based on the following differences: larger size; much paler; the ground color of primaries being at times almost white; and the median and basal brown areas contrasting strongly with the remainder of the wing.

To see size difference I measured the wingspan of two populations from British Columbia $(\mathrm{N}=30)$ and California $(\mathrm{N}=8)$. The specimens from British Colombia were $27-29 \mathrm{~mm}$ in male, 24-30 $\mathrm{mm}$ in female and those from California were $26-30 \mathrm{~mm}$ in both sexes. It seems to me that the size difference in $P$. georgii is not a good criterion for dividing the group.

\section{Discussion}

Several consistent morphological characters are present in the two species of Plemyria: costally 
distinct central fascia; one accessory cell; shape of termen of both wings; basally tapering uncus; large, tube-like juxta and transtilla; medially invaginated saccus; simple and membranous valva; developed hairs on laterodistal part of valva; one lateral large diverticulum of vesica; presence of colliculum in ductus bursae; linear arrangement of A1-A3-L1 on larval head; chaetotaxy of 3rd abdominal segment; biserial arrangement of crochets of ventral proleg; and long paraprocts.

The derived characters which support the clade of Plemyria were listed in the Diagnosis and monophyly. However, all derived characters are homoplastic characters, except one accessory cell of fore wing which is used consistently to diagnose the genus (e.g. Hulst 1896, Prout 1914, Forbes 1948). Thus, I compared two species of Plemyria with three outgroups, Thera variata, Dysstroma truncatum (Hufnagel) and Cidaria fulvata, and redefined the monophyly of Plemyria based on the following characters: single areole of fore wing; scalloping subterminal line of hind wing; well-developed pedunculi; large, tube-like juxta and transtilla complex; flat ventral surface of valva; distally scobinated aedeagus; large and tubular diverticulum; large, spinular cornuti; large, plate-like lamella antevaginalis; and absence of a pair of projection on pronotum.

Contrary to wing pattern of two species of Plemyria, the genitalia characters in both sexes show consistent pattern among different allopatric populations. Staudinger (1892) and Inoue (1955) designated the subspecies of dahurica and japonica, respectively. The designation of those subspecies was based on the differences of wing color and wing pattern elements. Although the genitalia of rubiginata are relatively simple, the comparison of syntypes (dahurica) and topotypical specimens (japonica) with European specimens demonstrates that the difference between allopatric populations is negligible. Thus, I have concluded that the subspecific designations are unnecessary.

Likewise rubiginata, the subspecific designation of georgii is ambiguous. Barnes and McDun- nough (1917) designated the subspecies, benesignata, based on the wing size, color and patterm. However, the variation of wing pattern in the same population and consistent genitalia characters between allopatric populations have concluded that benesignata is not a distinct population.

Acknowledgement: I thank Dr. K. Mikkola for very helpful comments and Drs. L. Ronkay (HNHM), M. Kelley (MCZ), W. May (MNHU), and F. Rindge (AMNH) for the loan of materials. The study was supported by CIMO, Finland and the Collection Grant from the American Museum of Natural History, New York.

\section{References}

Barnes W, and McDunnough, J. H. 1917: New species and varieties of Geometridae. Contributions to the Natural History of the Lepidoptera of North America: 224-261. - The Review Press. Decatur. Illinois.

Choi, S.-W. 1997: A phylogenetic study on genera of Cidariini from the Holarctic and the Indo-Australian areas (Lepidoptera: Geometridae: Larentiinae). - Syst. Entomol. 22: 287-312.

Cockayne, E. A. 1952: Interesting aberrations of British Macrolepidoptera bred by A. V. Hedges. - Entomologist 85: 265-270.

Cockayne, E. A. 1953: Aberrations of British Geometridae. - Entomol. Rev, and J. Variation 65: 161-169.

Curtis, J. 1837: British Entomology. Part XIV, t. 643.

Denis, M, and Schiffermüller, I. 1775: Ankündigung eines systematischen Werkes von den Schmetterlinge der Wienergegend. - Wien. $323 \mathrm{pp}$.

Ferguson, D. C. 1983: Geometridae. - In: Hodges, R. W (ed.), Check List of the Lepidoptera of America North of Mexico. E. W. Classey Limited. London.

Fletcher, D. S. 1979: Geometroidea. - In: Nye, I. W. B. The generic names of moths of the world. Vol. 3. British Museum (Natural History), London.

Forbes, W. T. M. 1948: Lepidoptera of New York and neighboring states. Part II. - Cornell Univ. Agric. Exp. Stat. Memoir 274. 261 pp.

Hannemann, E. 1920: Aus den entomologischen Vereinen. — Int. entomol. Zeit. 14: 121-123.

Hardwick, D. F. 1950: Preparation of slide mounts of lepidopterous genitalia. - Can. Entomol. 57: 231-235.

Haworth, A. H. 1809: Lepidoptera Britannica, - R. Taylor. London. 
Herbulot, C. 1962-63: Mise a jour de la liste des Geometridae de France. - Alexanor 2: 117-124, 147-154, 3: 17-24, 85-93.

Hoyningen-Huene, F. F. 1901: Aberrationen einiger estländischer Eulen und spanner. - Berliner Entomol. Z. 46: 309-319.

Hufnagel 1767: Forsetzung der Tabelle von den Nachtvögeln, welche die zte Art verselben, nehmlich die Spannenmesser (Phalaenas, Geometras Linnaci) enthalt. Berl. Mag. 4(6): 599-626.

Hulst, G. D. 1896: A classification of the Geometrina of North America. - Trans. Am. Entomol. Soc. 23: 245386.

Inoue, H. 1955: Descriptions and records of some Japanese Geometridae. - Tinea 2: 73-89.

Leraut, P. 1980: Liste systematique et synonymique des Lepidopteres de France, Belgique et Corse. - Alexanor 138-143.

McGuffin, W. C. 1958: Larvae of the Nearctic Larentiinae (Lepidoptera, Geometridae). — Can. Entomol. Suppl. 8: 5-104.

Meyrick, E. 1892: On the classification of the Geometrinae of the European fauna. - Trans. Ent. Soc. Lond. 1892: 53-140.

Mikkola, K., Jalas, I. \& Peltonen, O. 1985: Suomen perhoset. Mittarit I. - Tampere. $260 \mathrm{pp}$.

Patocka, J. 1994: Die puppen der spanner Mitteleuropas (Lepidoptera, Geometridae): Charackteristik und bestimmungstabelle der Gattungen. - Tijdschr. Ent. 137: 27-56.

Patocka, J. 1995: Die puppen dere Spanner Mitteleuropas. Unterfamilie Larentiinae, Tribus Lythriini, Xanthorhoi- ni, Larentiini und Cidariini (Lepidoptera, Geometridae). — Disch. entomol. Z. N. F. 42: 139-174.

Pierce, F. N. 1914: The genitalia of the group Geometridae of the Lepidoptera of the British Islands. - The Elms, Liverpool. 88 pp.

Prout, L. B. 1898: Some named Varieties in the Larentiidae. - Entomol. Rec. 9: 200-201.

Prout, L. B. 1914: Geometridae Palearctica. — In: Seitz, A. (ed.), Die Gross-Schmetterlinge der Erde. Bd. 4: 216 220. Verlag A. Kernen, Stuttgart

Prout, L. B. 1938: Geometridae Palearctica. — In: Seitz, A. (ed.), Die Gross-Schmetterlinge der Erde. Bd. 4. Supplement: 111-115, 245. Verlag A. Kernen, Stuttgart.

Rebel, H. 1910: Fr. Berge's Schmetterlingsbuch nach den gegenwäartigen Stande der Lepidopterologie. - E. Schweizerbart'sche Verlag, Stuttgart.

Rindge, F. H. 1955: The type material in the J. S Smith and G. D. Hulst collections of Lepidoptera in the American Museum of Natural History. - Bull. Amer. Mus. Nat, Hist. 106(2): 95-172.

Seppänen, E. J. 1954: Die Futterpflanzen der Gross schmetterlingsraupen Finnlands. - Animalia Fennica 8. Werner Söderström Osakeyhtiö. Porvoo. 414 pp.

Stauder, H. 1923: Larentia bicolorata Hufn. bei Innsbruck. — Int. entomol. Zeit. 17: 92-93.

Staudinger, O. 1892: Lepidopteren des Kentei-Gebiirges. — Dtsch. entomol. Z., Iris 5: 300-393.

Strand, E. 1901: Beschreibung neuer Schmetterlingsformen aus Norwegen. - Schrif. Naturf. Ges. 10: 285-286.

Suomalainen, E. 1965: On the chromosomes of the geometrid moth genus Cidaria. - Chromosoma (Berl.) 16: 166-184.
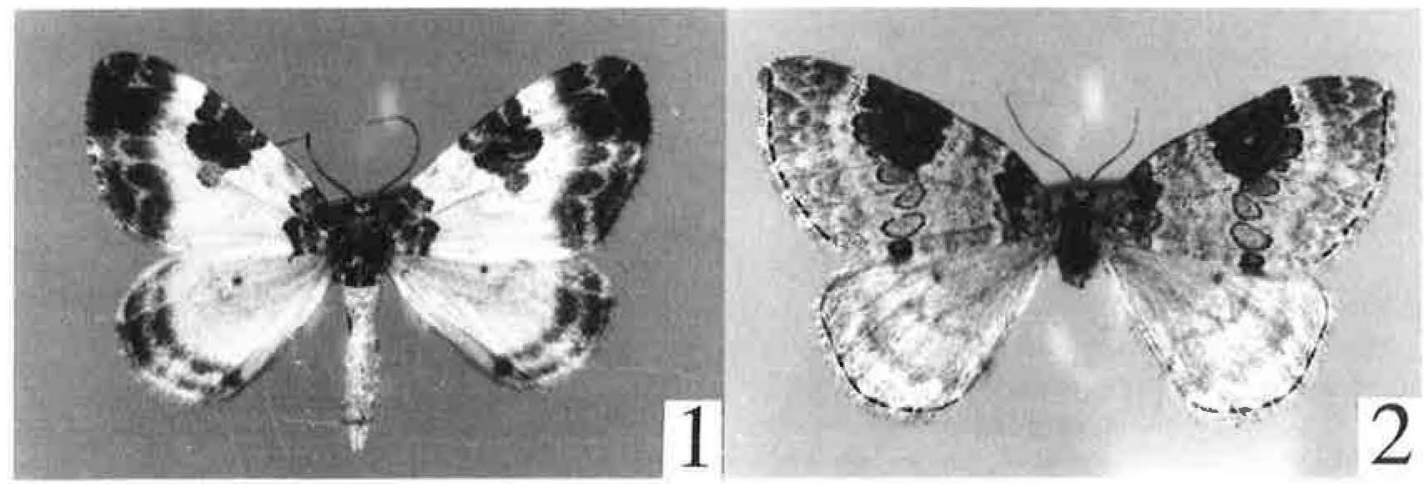

Figs. 1-2. Adults of Plemyria: 1: P. rubiginata, $\sigma^{\prime}$, wingspan $21 \mathrm{~mm}$, labelled "Kohfidisch Blgd., Austria, 23.VI.1957. leg. Dr. Issekutz "in HNHM; 2. P. georgii, \&, wingspan 29 mm, labelled" Victoria B.C., 23.VII.1921. leg. W. Downes" in MCZ. 

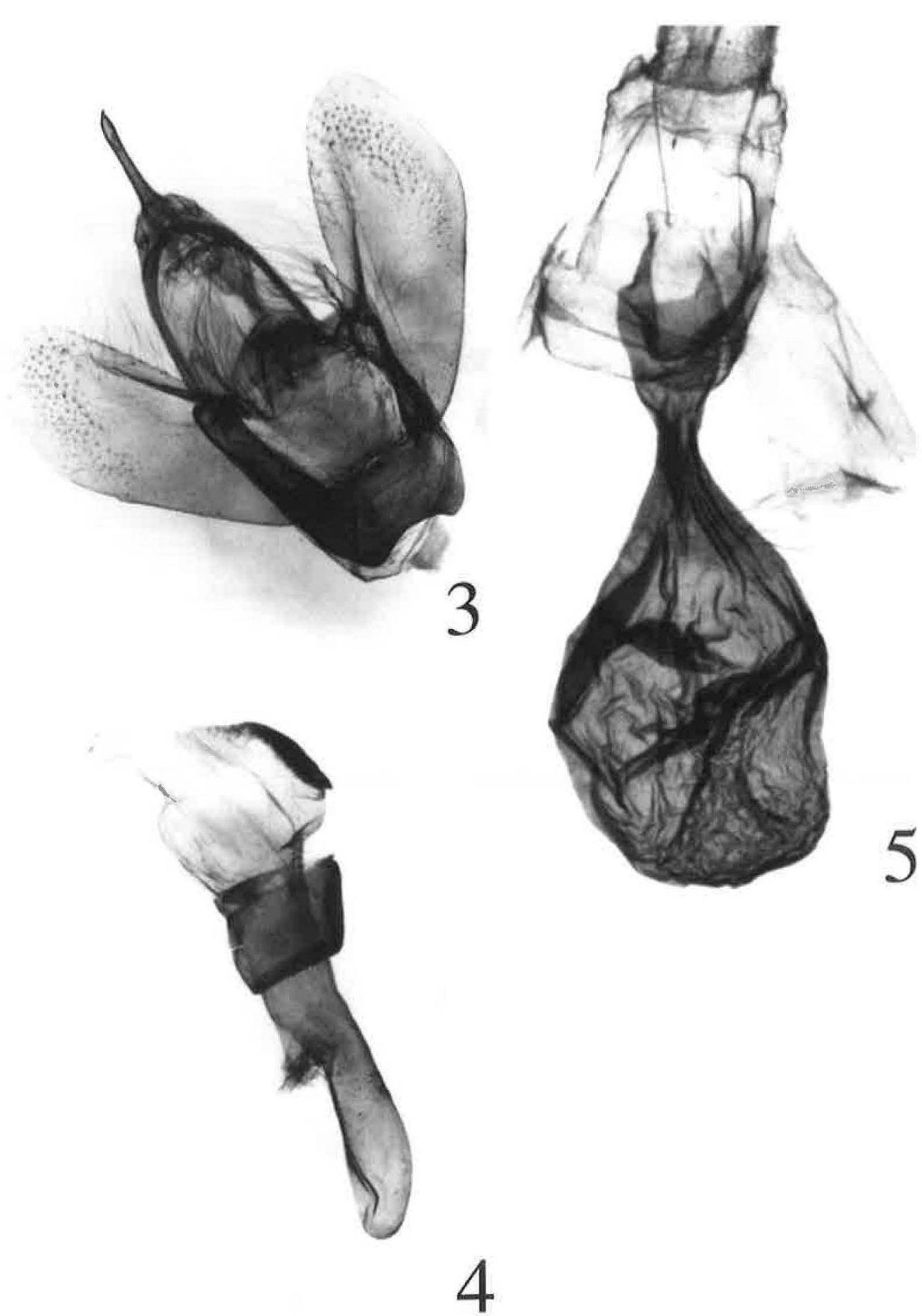

Figs. 3-5. The genitalia of $P$. rubiginata: 3: Male genital capsule; 4: Aedeagus with everted vesica; 5: Female genitalia. 


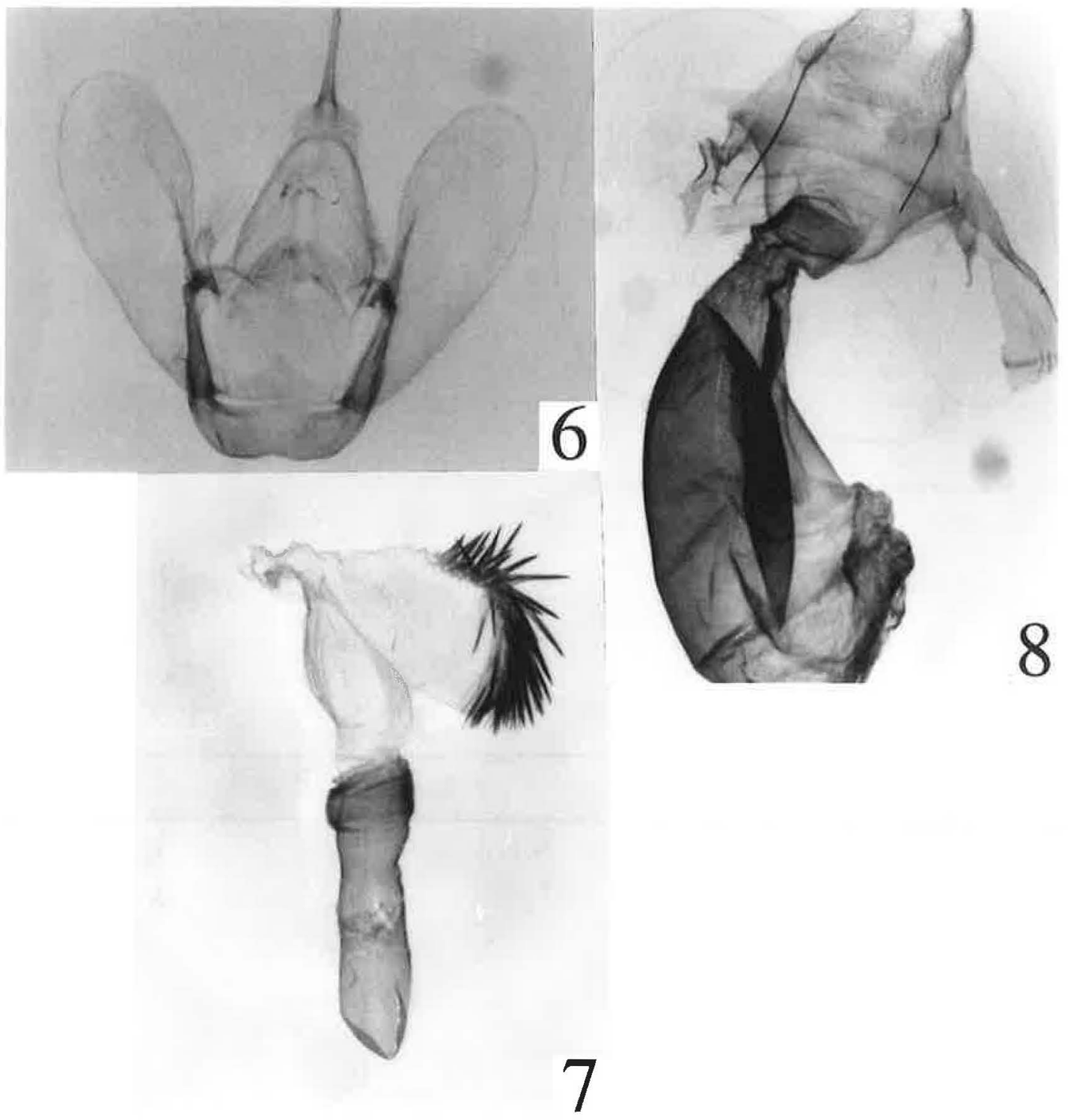

Figs. 6-8. The genitalia of $P$. georgii: 6: Male genital capsule; 7: Aedeagus with everted vesica; 8: Female genitalia. 


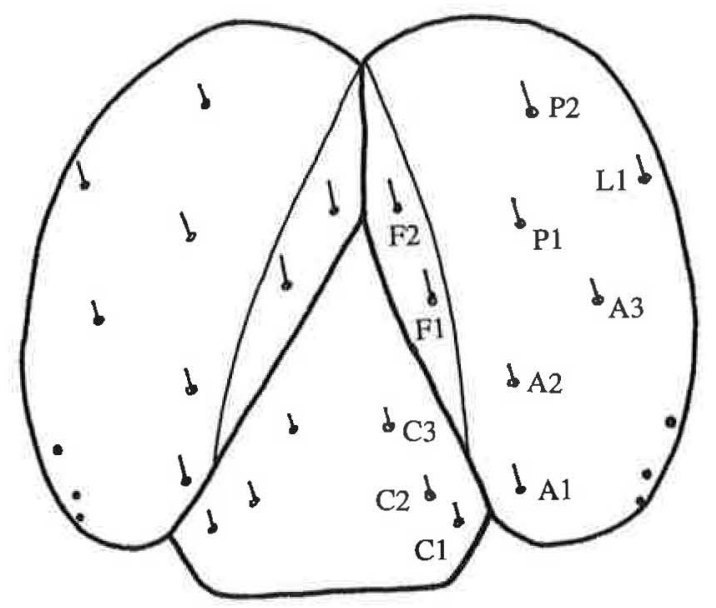

Fig. 9. Larval head of $P$. rubiginata with chaetotaxy.

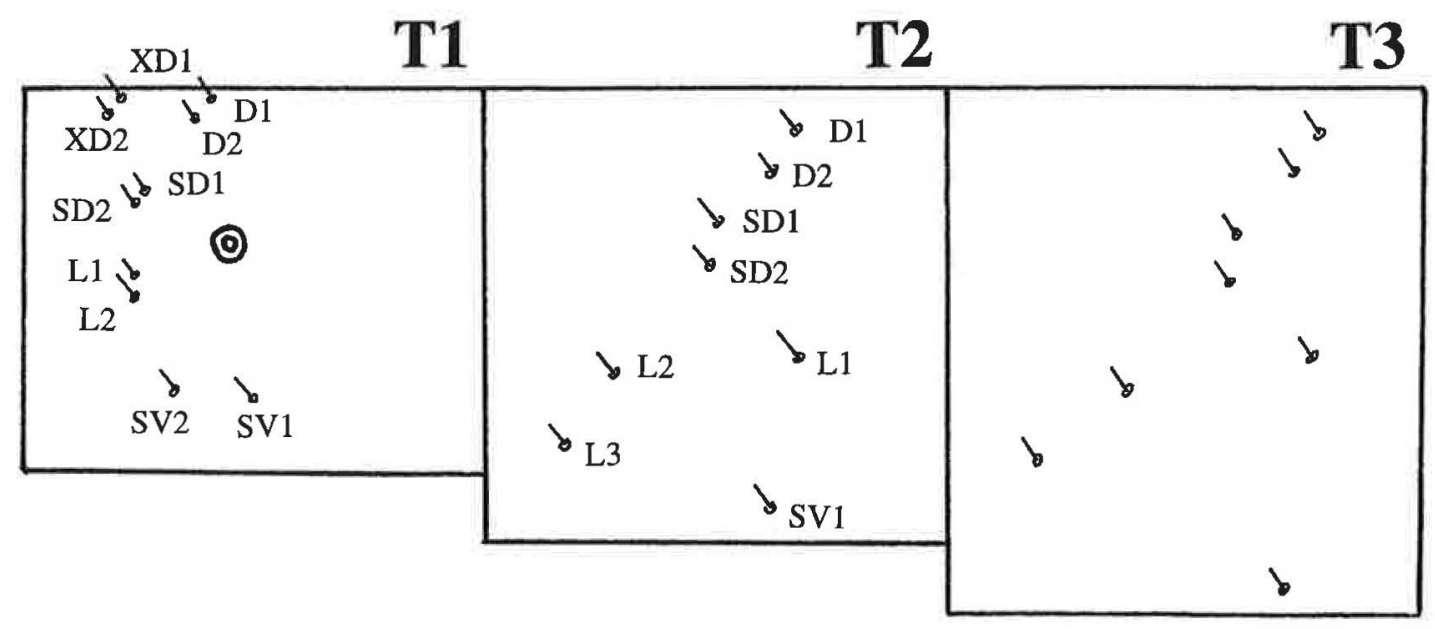

Fig. 10. Larval thorax of $P$. rubiginata with chaetotaxy. 


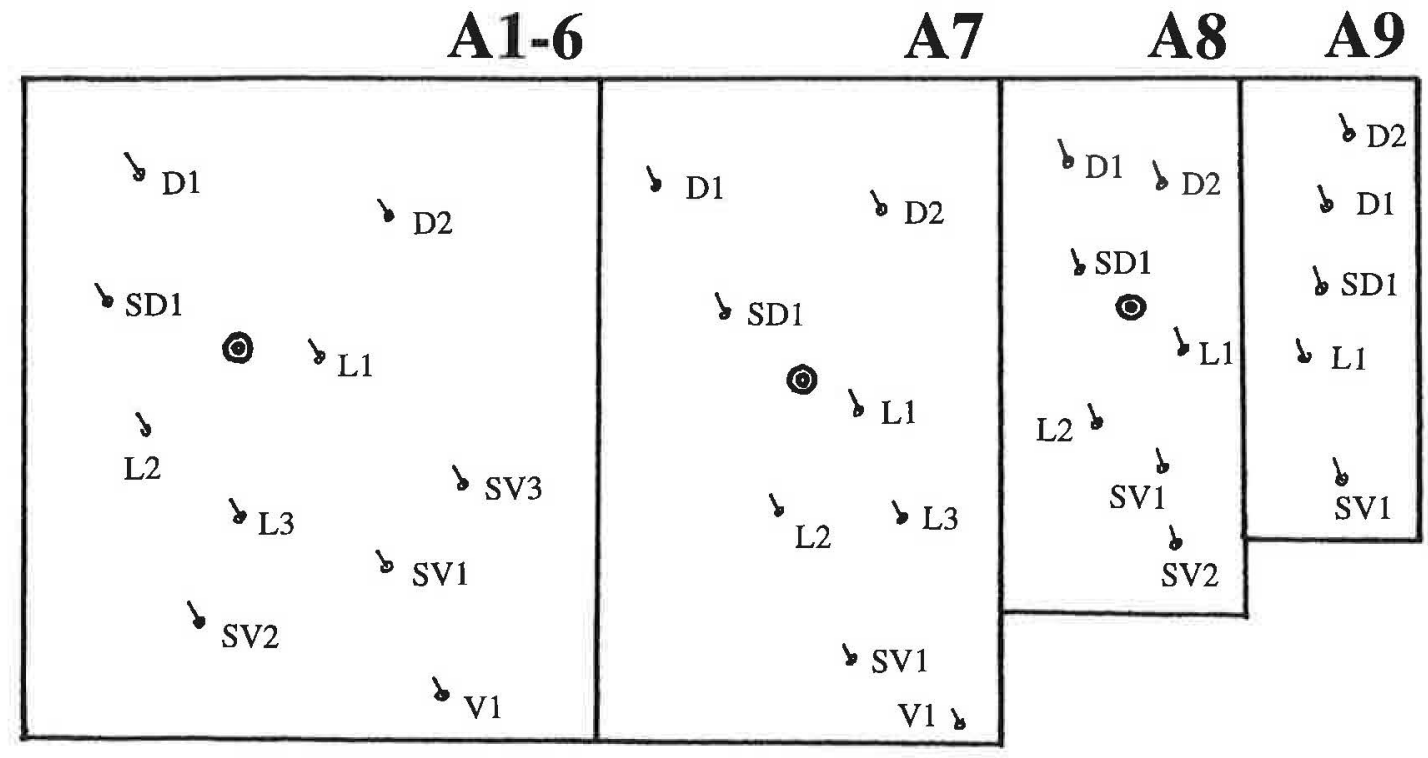

Fig. 11. Larval abdomen of $P$. rubiginata with chaetotaxy.

Fig. 12. Pupae of $P$, rubiginata. - Fr: Frons. - Pe: Postclypeus. - Lb: Labrum. - O: Ocelli. - La: Labium. - Pr: Proboscis. — Fl: Foreleg. — Ft: Foretibia. - Ml: Midleg. — A: Antennae. - Hl: Hindleg. - FW: Fore wing.

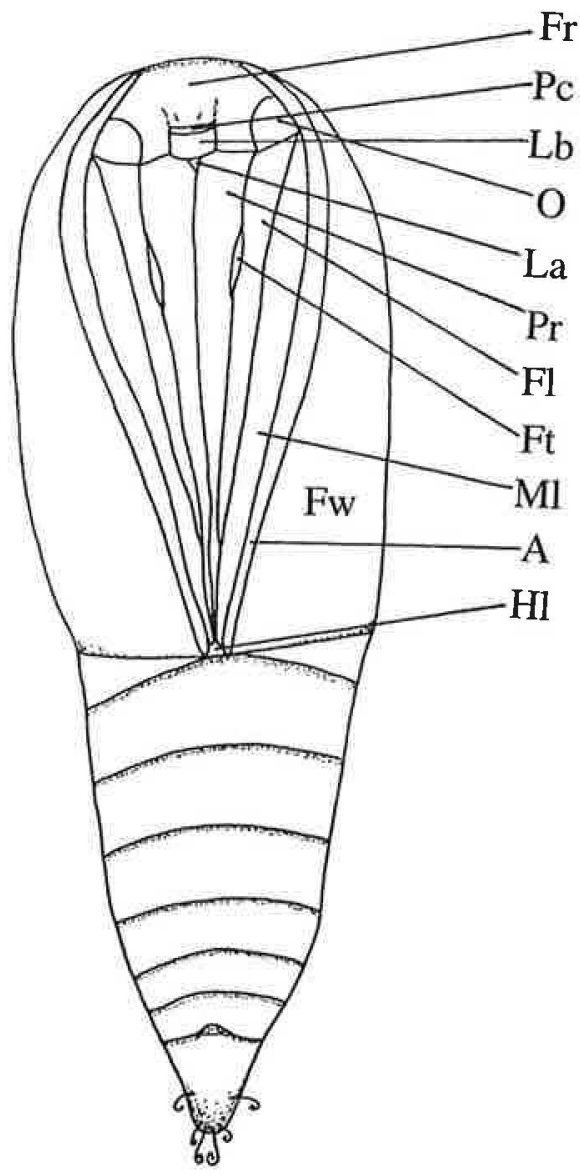



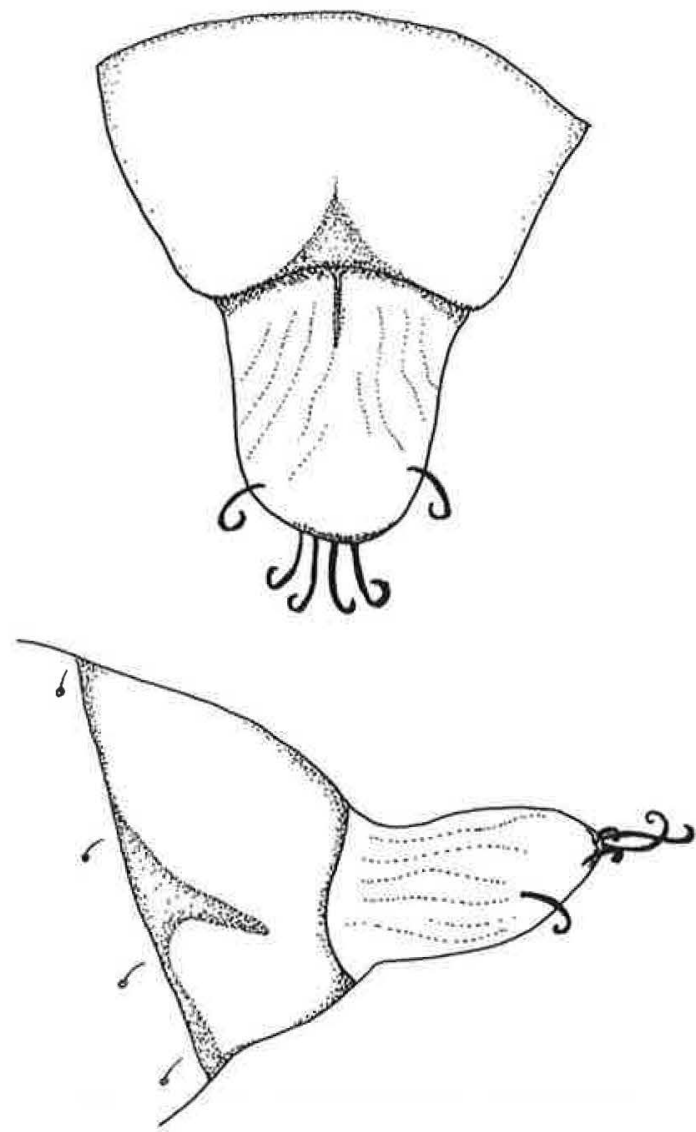

Fig. 13. Pupal cremaster of $P$. rubiginata.. 